\title{
In Praise of Improvisation in Brazilian Soccer: Modernism, Popular Music, and a Brasilidade of Sports
}

\author{
Bernardo Borges Buarque de Hollanda
}

\author{
Translated by John Thomas Maddox
}

Over the course of the twentieth century, popular music and soccer gradually developed into two great icons of Brazilian identity. The crystallization of this image of the country became commonplace and today it has an international reach. These two symbols of nationality have had the direct effect of elevating the self-esteem of the majority of the population. The prestige of popular music and the recurrent feats of the "Seleção Brasileira"-the Brazilian national soccer team-at the World Cup act as a kind of counterbalance to the ample distrust of political institutions, patterns of immoral conduct, and the dim prospects for individual economic mobility that are characteristic of Brazilian society. In particular ways and at distinct moments, symbols of popular music and soccer were both incorporated into the very edifice of the idea of brasilidade; and while on some occasions the two symbols overlap, in the context of Brazilian modernism, music and soccer were initially conceived of as opposites.

The purpose of this essay is to expose the trajectory of both of these symbols to the light of modernist assumptions, whose center in Brazil was the Semana de Arte Moderna-the Modern Art Week-of 1922. I also intend to provide evidence for how the convergence between popular music and soccer was realized thanks to the idea of improvisation. Often seen as a quintessentially Brazilian ability, improvisation is naturalized in native discourse and is taken to signify an aptitude to adapt and to find quick solutions, to be able to resourcefully rearrange the unforeseen events that occur in the most varied kinds of ordinary situations. My argument asserts that this particular conception of the unforeseen is at the very foundation of the creative potential identified by the sociologist Gilberto Freyre in his legitimization of soccer.

The interest of intellectuals in popular music and in its folkloric manifestations goes back to the Romanticism of the 1800 s and, in particular, to the last quarter of the nineteenth century. The figure of Sílvio Romero can be considered emblematic among the Generation of 1870, who sought to salvage popular poems, traditional stories and disseminate oral literature from the most obscure regions of the country. Similar to what was occurring in Europe, as the British historian Peter Burk shows in Popular Culture in the Modern Age, the gathering of a musical repertoire was incumbent upon the lettered class of the time. The preservation of folkloric material, "pieces from an antique shop" (12), as sociologist Renato Ortiz would say, was part of an ideal of rescuing cultural goods that would maintain intact the traces of an incipient nationality.

During the first decades of the twentieth century, missionary activity on behalf of music was still in force, though with new faces and in different contexts. Graça Aranha, in his essay "Espírito moderno" (Modern spirit, 1924), already pointed to popular music as the unifying element of a Brazilian national character. The influence of German Romanticism caused Aranha, most famous for his novel Canaã (Canaan, 1903), to revisit the idea of the existence of a "spirit of the people." The singularity of each nation could be found in a specific cultural manifestation that would unite the diverse aspects of popular traditions. In the Brazilian case, Graça Aranha saw music as the genuine expression and the legitimate representation of nationality.

During the 1920s and 1930s, modernism would dawn in Brazil with a renewed enthusiasm for folklore and popular music. Mário de Andrade, Renato Almeida, and Heitor Villa-Lobos, among others, updated the tenets of Romantic nationalism and pursued the research and conservation of the rhythmic, melodic, and poetic materials of Brazilian music. The project of tracking down anonymous songs dispersed across the rural interior of the country had a slant not only of ethnographic incursion but also of ethnic reach. In the trips these intellectuals made-whether to Mato Grosso, to Amazônia, or to the small towns of the Northeast-there was a marked interest in black and indigenous culture. Previously rejected or considered derivative in the face of European civilization, indigenous and African traditions now became so valued that their cultural contributions could be considered fundamental pillars in the affirmation of national identity. 
The attention of modernist writers in the 1920s and 1930s would not only be turned to rural regions or to the unknown corners of the vast interior of the country; urban areas, with their large black populations, with their outskirts-the poor subúrbios-still somewhat rural in character, with neighborhoods that existed at the margins of discriminatory modernization, were also a target of interest. São Paulo, Recife, and Rio de Janeiro represented the main urban poles of attraction for Brazilian modernists.

With regard to the city of Rio de Janeiro, the anthropologist Hermano Viana, in his book O mistério do samba (The Mystery of Samba, 1995), tells of an emblematic episode of cultural circulation. In 1926, writers Gilberto Freyre, Sérgio Buarque, and Prudente de Morais Neto met with the musicians Pixinguinha, Donga, and Patrício Teixeira. This nocturnal encounter, which took place in a traditional Rio bar, would be the nexus between erudite modernist intellectuals of elite origin and black popular composers of the subaltern urban sectors.

Their attempt at establishing which elements should be taken to belong to brasilidade and integrating them into the so-called national culture would orient the actions of intellectuals like Mário de Andrade and Villa-Lobos after the 1920s, under the aegis of the 1930 Revolution. The political and institutional path, mediated primarily by Gustavo Capanema and Rodrigo Melo Franco de Andrade of the Ministério da Educação, or by the Serviço do Patrimônio Artístico Nacional, would become a privileged site for popular music in the sphere of national identity during the Vargas Era, as the critic Antônio Candido describes in his essay "A Revolução de 30 e a cultura" (The 1930 Revolution and Culture). Thus, in spite of its assimilation by the state and notwithstanding the influence of the recording industry and the mass media (radio, in particular) that absorbed a large part of these composers' production in the 1930s and 1940s, popular music would constitute yet another of the domains within the discourse of national traditions that the modernists would take to be genuine and pure.

\section{****}

Soccer took a very different course and was received in a diametrically opposed manner by modernist intellectuals during the decade of the Semana de Arte Moderna. If popular music and folklore belonged to the preservationist perspective of the modernist project, the soccer phenomenon in Brazil of the 1920s was far from the missionary concerns of these writers. The intense presence of sports in Brazilian social life reached such an extreme that Mário de Andrade, in Macunaíma (1928)—Brazil's modernist masterpiece-represented soccer in fiction as one of the three plagues that were destroying the country: alongside the coffee leaf miner and the pink bollworm, soccer, unleashed by an enraged Macunaíma, was a plague that infested cities and spread throughout the fields of Brazil.

It is not surprising that, in this literary rhapsody, Mário de Andrade's lazy hero was averse to playing sports. The introduction of soccer to Brazil at the dawn of the twentieth was realized by young athletes, descendents of European immigrants (Charles Miller in São Paulo, Oscar Cox in Rio de Janeiro) or children of Brazilian elites (Marcos Carneiro de Mendonça, goalkeeper of Rio's Fluminense team) who would gather at the refined social clubs of the big cities. These new personages on the national stage, almost all of them law, engineering, and medical students linked to the Positivist ethos of science, brought not only the latest innovations from Europe, but also, above all, a different mentality that lauded the importance of training, discipline, and the cult of the body.

According to the historian Nicolau Sevcenko, in a long chapter about the irradiant capital of the Republic at the beginning of the twentieth century (Rio de Janeiro), the technological and scientific transformations European capitalism had been undergoing since 1870 reached Brazil at the beginning of the twentieth century and had effects on all levels of society. Industrialization and urbanization brought profound changes to the rhythm of everyday life. The formation of working sectors, the rising waves of European immigrants, and the growing demographic flux even caused the architecture of cities to be planned out to function like a human body. Mechanization and speed were the imperatives of "modern times."

Modernist writers' disdain or repudiation of soccer occurred in proportion to the way it came with this swell of changes. Soccer-an import-originated from a European matrix transplanted by an Anglophone and Francophone elite hungry for novelty and the exotic. Under the aegis of Nativism, Positivism, and modernist Nationalism, soccer constituted yet another phenomenon typical of Brazilian cultural dependence, one also situated in the homogeneous formation of an urban-industrial society. The importation of soccer represented the adoption of yet another luxury item, with its English language and previously unknown British uniforms.

Admired by the elites of Rio de Janeiro and São Paulo, amateur soccer in the 1920s provided a sort of aristocratic pastime resulting from the fruition of free-time and leisure, for spectators as well as players. For the Rio and São 
Paulo bourgeoisie, sports latently brought the positive values of competition, initiative, equal rights, and individual improvement.

In this sense, it is understandable that soccer was sifted out by the narrow interests of 1920s modernism. Nevertheless, indicators of soccer's presence occurred here and there, in a poem or a story, and became more marked each year. Mário de Andrade, always attentive to quotidian events, refers in his "Paulicéia desvairada" (Hallucinated City, 1922) to a Sunday when soccer mobilizes the city:

Hoje quem joga?. . . O Paulistano

Para o Jardim América das rosas e dos pontapés!

Friedenreich fez goal! Corner!

Que juiz!

Gostar de Bianco? Adoro.

Qual Bartô...

E o meu xará maravilhoso!. . .

- Futilidade, civilização. . . (47)
Who's playing today?. . . The Paulistano

For Jardim América, garden of roses and kicks!

Friedenreich scored a goal! Corner kick!

What a referee!

Do I like Bianco? I love him.

How about Bartô ... .

How about my wonderful namesake! . . .

- Futility, civilization. . .

While soccer existed in the day-to-day life of the residents of São Paulo, for Mário de Andrade it signaled yet another futile fad among innumerable others that came from a European reality. The poet-columnist sensitively captures the thrill of those rushing to watch a match, but also points out the trace of elitism in a sport marked by foreign expressions and played violently in a traditional social club in the city.

The reference to Arthur Friedenreich is significant, because he was the first idol of Brazilian soccer. Active during the 1910s and 1920s, Friedenreich was descended, significantly, from a German immigrant and a black washerwoman. As historian Nicolau Sevcenko indicates, Friedenreich and Edu Chaves, the latter an ace aviator, were the two great sports idols from the city of São Paulo. Friedenreich, known as El Tigre, would be a target of interest at the beginning of the 1930s for another modernist writer, Menotti del Picchia. The author of the poem Juca mulato wrote the script for the film Campeão de futebol (1931), in which he paid homage to the crack soccer player of the time, alongside Feitiço and other players.

Soccer was not immune to the pen of Oswald de Andrade. Among the peripeteias of his book Memórias sentimentais de João Miramar (Sentimental Memories of João Miramar, 1924), in the poem "Bungalow das rosas e dos pontapés," he lifts a verse from Mário de Andrade:

\author{
Bondes gols \\ Aleguais \\ Noctâmbulos de matches campeões \\ E poeira \\ Com vesperais \\ Desenvoltas tennis girls \\ No Paulistano \\ Paso doble. (88)
}

\author{
Streetcar goals \\ Aleguais [Typical Sáo Paulo soccer cheer] \\ Sleepwalkers of champion matches \\ And dust \\ With afternoon entertainment \\ Unwrapped tennis girls \\ At the Paulistano \\ Paso doble.
}

Oswald de Andrade records in his free verse, in the form of photographic flashes, the presence of soccer in the modern city of São Paulo. Alongside the streetcars, symbolic elements of progress, soccer goals are integrated into this new time of unrest and frenzy that spread through Brazil's metropolises. Soccer acts as an aspect of cosmopolitanism that brings life in São Paulo in line with the new spectacles of European cities. Years later, in an article written for the Estado de São Paulo, Oswald de Andrade would refer again to soccer, but now as an epiphenomenon of the religious foundation of modernity, alongside cinema festivals and politics.

In 1927, Antônio de Alcântara Machado published the short story "Corinthians (2) VS Palestra (1)" (Team Corinthians 2 versus Team Palestra 1). In this story, soccer does not appear the same way it does in Mário de Andrade and Oswald de Andrade. It is not just another thematic motif that is imposed because of its presence in the everyday life of the city. The game occupies the center of the story and its language is instilled in the structure of the text. Alcântara Machado narrates the game, capturing the movements, inflections, and nuances of a soccer match. The São Paulo writer emphasizes the orality of the game, the characteristic interjections of the spectators, the convolutions of the players around the ball. With this creative crónica in short-story form, the author performs with soccer the linguistic experiments that so fascinated the modernists in the 1920s. 
The 1930s inaugurated a new stage in the history of soccer and, accordingly, the modernists' relationship with it. If, in the previous decade, soccer was appreciated because of its appeal as a phenomenon of urban lifestyle and as a means of stylistic experimentation, as modernism entered its second phase in the 1930s, the question of national representation became the axis of the modernists' concerns. This can be verified because in that decade soccer championships came to have an intercontinental dimension: the first three World Cups were organized in 1930, in Uruguay; in 1934, in Italy; and in 1938, in France. The latter, the first aired on radio, also showed the importance of mass media to the process of popularizing soccer in Brazil on an ever-expanding national scale.

These tournaments led to South American championships: matches against Uruguayans, Argentines, and Chileans in annual contests respectively titled Taça Rio Branco, Copa Roca, and Copa O'Higgins. Such games were crucial to the formulation of the notion of identity, inasmuch as they occasioned the discussion of the country's image abroad and reinforced an idea of a national unity that is dependent upon sport. Modernists, throughout the decade, were not adverse to the repercussions of this debate in Brazilian social life.

The modest participation of Brazil in the Word Cups of 1930 and 1934 brought to the surface discussion about the composition of the Brazilian team and the hegemony of its white players. The triumphant experiment of a team with white, black, and mulato athletes at the Copa Rio Branco in 1932, when Brazil defeated Uruguay, world champion two years earlier, contributed to the growing pressure of professionalization. After 1933, with the professionalization of soccer and the official integration of black and mulato players, elite amateur play ceded to the new reality of sport. The strong performance of black players opened the door for an association between sports identity and ethnic difference in popular constructions of the Brazilian people.

The ethnic eccentricity perceived in soccer reached its apex during the 1938 World Cup in France. Though Brazil did not win, coming in third, the performance of Leônidas da Silva and Domingos da Guia strengthened the feeling that sport had a symbolic relationship with the homeland. Oswald de Andrade, far from being a sports enthusiast- though he played soccer, swam, and boxed in his youth-recorded the country's soccer successes abroad in his telegraphic poem "E a Europa curvou-se ante o Brasil" (Europe Bows Before Brazil). In this, seconding the report of the theater critic Décio de Almeida Prado, Andrade refers to the excursion of the São Paulo amateur team, the Paulistano, to the European continent in 1925: " 7 to $2 / 3$ to 1 /the injustice of Cette/4 to $0 / 2$ to $1 / 2$ to $0 / 3$ to $1 /$ And a half dozen in the Portuguese's face" (Poesias 114).

The image evoked by the poem suggests that Europeans, and the Portuguese in particular, prostrated themselves before the Brazilians' feats. By way of soccer, Brazil-like a sorcerer-was able to invert the traditional relation of dependence with the Old World powers. The modernists unveiled a medium in which the idea of Brazilian inferioritylater sketched in the formulation of the dramaturge and sports journalist Nelson Rodrigues as the "complexo de viralatas" (stray-dog complex) (51-52)—could be overcome. Mário de Andrade, in a 1939 column entitled "BrasilArgentina," also accentuates this transformation that is confirmed by soccer. The process of its appropriation into Brazilian national identity acquires an anthropophagous character in the following passage:

Dozens of different tribes organizing themselves, enmeshing themselves like gears, receiving a thousand and one foreign influences, but accepting from others only that which was really assimilable and immediately conforming the imported element to the national fiber. ( $O$ baile 81 )

The sensations described by Mário de Andrade throughout his crónica show themselves to be fluid, transferable-in an instant - to the Brazilian team, to the Argentine team, and from the latter, even to the Greeks. What one deduces from his meanderings regarding the game is the ability of soccer to be what Roberto Schwarz called "nacional por subtração" (national by elimination): that which embodies the collective representations of the nation, purging it, as Andrade wrote, of the "imported element" (81).

Mário de Andrade's vision of soccer also incorporated the anthropophagy conceived by Oswald de Andrade, which affirmed the Brazilian capacity for deglutição (swallowing): the assimilation of foreign influences and their transformation into genuine national expressions. Thus modernist interpretations received their own contours; they also saw in soccer a way to bring them closer to their conceptions of brasilidade.

The 1940s were essential to the establishment by modernist writers of improvisations in representations of Brazilian soccer. In this period, regionalists from the Northeast (such as the sociologist Gilberto Freyre, novelist José Lins do Rego, novelist Rachel de Queiroz, and poet Jorge de Lima) entered the scene, the majority of them residing in Rio de 
Janeiro where they gathered at the bookstore Livraria José Olympio. The 1938 World Cup provided Freyre, the author of Casa-grande e senzala (The Masters and the Slaves, 1946), with an occasion to identify a distinct Brazilian style of playing soccer.

In the notes of his book Sociologia (Sociology, 1943), Gilberto Freyre contrasts Brazilian futebol-arte (soccer-art) with European futebol-científico (scientific soccer). His observations would later be perfected in his preface to Mário Filho's classic book O negro no futebol brasileiro (Blacks in Brazilian Soccer, 1947). Freyre's vision of soccer would be developed decades later by Roberto DaMatta, responsible for anthropologically reflecting on the figure of the malandro (the street-wise rogue) and on the practices of everyday Brazilian life, on the improvisational concept of systematically outsmarting the rules through the jeitinho brasileiro (the Brazilian "way").

According to Freyre, it was Leônidas da Silva's performance in the 1938 World Cup that prompted him to see how the Brazilian soccer star molded the British sport to a typical mulato style of play that privileged individual quality over collective organization. The difference revolved around the incorporation of improvisation, which for Freyre was understood as a capacity linked to skill, surprise, and the creative usage of micro-spaces on the field. Such an understanding would be Freyre's key to explaining Brazil's success in international matches.

Freyre and José Lins do Rego would become the two great names among the intellectuals of this period to highlight the subject of soccer in Brazilian culture. To do this, these regionalist scholars from the Northeast availed themselves of the essential perspectives of journalist Mário Filho. A zealous, indeed militant, promoter of sports in Brazil, he regularly published books on soccer throughout the 1940s: Copa Rio Branco 32 (1943), Histórias do Flamengo (1945), O negro no futebol brasileiro (1947), and e Romance do football (1949). In them, the journalist strove to recount the history of Brazilian soccer, combining his personal memories with innovative research based on the oral histories he conducted with former players.

The point here is that the work of Mário Filho in the 1940s provoked modernist interpretations that identified the important role improvisation played in Brazilian soccer and, more broadly, in Brazilian society. Mário Filho's first book, the story of how Brazil won the Rio Branco Cup-a tournament in which they played against Uruguay, two-time Olympic champions and World Champions in 1930-has an introduction by José Lins do Rego, in which he makes a direct reference to the idea of improvisation as a Brazilian national ethos. In an enthusiastic tone, he says,

The young men that won in Montevideo were a portrait of social democracy, where Paulinho, the son of an important family, united with the black Leônidas, with the mulatto Oscarino, with the white Martins. All this done in the good Brazilian style, with the most sympathetic improvisation [my italics]. Reading this book on soccer, I believe in Brazil, in the eugenic qualities of our mestizos, in the energy and intelligence of the men that the Brazilian land forged with diverse bloods, giving them an originality that one day will shock the world. (7-8)

In 1947, four years after Filho's book appeared, it was Freyre's turn to theorize about Brazilian originality in this sport and the physical lability of mestiço athletes. In O negro no futebol brasileiro, Freyre avails himself of an astute discursive strategy. He capitalizes on the fact that his reflections took account of the period between the 1920s and the 1950s when the nation's soccer was taken to be inferior to the soccer played in Argentina and Uruguay. By privileging exhibition at the expense of competition, by opposing science and art as styles of play, the sociologist highlights the aspects that he wanted to see in the Brazilian player-a metaphor of the common man-at a time when the country had not distinguished itself with international titles.

In Freyre's vision, the value of improvisation in Brazilian soccer emerged out of the force of traditional play against the character of modern sports. It is the ludic, amateurish sphere, to put it in objective terms, tied to the rural environment or to the small towns of the interior, that allowed Brazilian soccer to be played in a unique way. According to his own terms, soccer in Brazil would have irrational, psychological ingredients:

This, when these energies or these impulses, instead of being sublimated or satisfied by rural sports or quasi-sports on holidays or ordinary days, dominant in patriarchal Brazil—cavalhadas [horse shows], chasing oxen, hunting, fishing, entire nights of samba or exhausting dance, long walks through the sertão [backlands] hunting for Indians or fugitive slaves, blacks running from foremen or the melancholy of the agrarian routine on plantations and farms-don't debase themselves socially or morally in exploits like the bandits of the Northeast or the roundhouse kick of capoeira, celebrated in the history of Brazilian society. Entirely national types of sport. ("Prefácio" 24) 
In this sense, the prefaces of Rego and Freyre serve as an intellectual seal to the works of Filho. The Paraíban novelist and the Pernambucan sociologist affirm the literary qualities and gifts of the journalist; at the same time, they nourish themselves with the aspects considered most relevant in this serial attempt to write an almost novelized historiography of Brazilian soccer. Based on Filho, Rego and Freyre saw two original phenomena originating in the heart of Brazilian soccer: the strength of black racial heritage and the incorporation of music into playing style. According to Freyre,

The characteristically Brazilian foot, it can be said, is still, in large swaths of the country, the little foot of the mulatto. It has a sort of elegance in contrast with the enormous feet of the Portuguese, the English, the blacks, and the Germans. The agile but delicate foot of capoeira, of the samba dancer, of the soccer player, place Brazilian technique closer to a Dionysian dance than to the Apollonian British style. (Sobrados 626)

It was during this period that the idea crystallized, today a stereotype, that blacks introduced movement to the rigid European body. While tactical and technical systems in Europe were fixed-such as the WM formation created in the mid-1920s by the English player and manager Herbert Chapman-Brazilian discourse, of which Freyre was the greatest representative, accentuated an aversion to training, confident in the ability of the mestiço athlete to improvise at game time. This kind of player was the national type, explosive and irrational, incarnate in the striker Leônidas da Silva. According to such a belief, the player did not need to be boxed in, established a priori in the form of training through systematic repetition.

Flexible and versatile corporeal skill, in turn, was not a creation that originated exclusively in soccer-it was a transplant. The physical agility and unexpected "fakes" lauded by Brazilian commentators were descended directly from manifestations within popular music and folklore, whether the sway of the hips originating in carnival, the sinuous steps samba brought into being, or the dodges and feints that came from capoeira. In this way, the legitimacy of soccer in Brazilian culture supported itself on an already established element of national identity: astuteness and improvisation. Music gave soccer what modernist intellectuals had detected in it in the 1920s: namely, the criteria and the sources of brasilidade.

The link between music and sports, however, was not an isolated fact restricted to Brazil. Anthropologist Eduardo P. Archetti, in his recent book Masculinities: Football, Polo and the Tango in Argentina (1999), shows that an analogous process of nationalization of foreign sports by way of music occurred in other Latin American countries. In Cuba, baseball, imported from the United States, was incorporated into the discourse of nationality through its adaptation to the typical Cuban music style: salsa. In Argentina, national identity was linked to soccer through an association with the tango.

But Freyre, in one of a series of lectures given in the United States in 1944-gathered in a book under the title Interpretação do Brasil (Interpretation of Brazil)—sought to endorse his thesis of the similarity between dance and the Brazilian form of soccer not only in the national context, but also in a broader Latin American one. Appealing to foreign writers, Freyre offered this perspective:

After I published my first notes about these two matters-regional ways of dancing and playing soccer, soccer even as a dance with something African in it-I read an excellent passage by Waldo Frank in which he finds that tango is a "sculptural dance-music"; and at the same time he says that, observing a group of Brazilians playing soccer, he noticed that they played trying to take the ball to the goal as if they were executing the "melodic line of a samba." He reproduces almost the same observation I made in an article written in 1938 that I am sure Waldo Frank read, as well as another I published in 1940 about the various Brazilian ways of dancing from different areas_-from Bahia to the misionera region of Rio Grande-the dances of carnival. (173)

As part of a larger process that occurred in several countries, soccer became acclimated to Brazil through intellectual discourse and through its principal representative, already established in Brazilian music: the samba. In this sense, even before the Northeastern regionalists' formulation about brasilidade in sports, Mário de Andrade, in the aforementioned 1939 crónica, already analyzed soccer in light of musical imagery. He mentions the elasticity, the subtle tricks, the samba-like ways of fooling opponents, the rapid turns of the soccer ball; invoking the figure of Dionysus, Greek god of intoxication, just as Freyre would later do. Hardly worried with how the game turned out, Andrade confessed that he was captivated: "Gorgeous! What a marvelous dance, this game of soccer!" ("Brasil- 
Argentina" 81). It was, after all, a true "hummingbird ballet" behind the ball. This impression was confirmed by Paulo Mendes Campos, another occasional author of sports crónicas:

Mário de Andrade was a soccer enthusiast. He complained of the 350 commitments that impeded him from constantly being at the stadiums. In his books, there are some references to soccer, always given with deep knowledge. Mário had a special proclivity for the famous midfielder Brandão. He said, with raised inflection: "he is a won-der-ful dancer!" (92)

Such perspectives ended up finding resonance among the players themselves. In a speech given on September 1 , 1967 at the Museum of Image and Sound in Rio de Janeiro, the famous defender Domingos da Guia-who even refers to the traditional idea of malandragem—established the following relationship between soccer and music:

My older brother used to tell me: a malandro [crook] is a cat that always lands on his feet. [. . .] You're no good at dancing? I used to really be good at dancing and that helped me on the field. [. . .] I swerved a lot. [. . .] You know, I remembered them. [. . . ] I invented that short dribble imitating the miudinho-the "little one"that kind of samba. (qtd. in Moraes, M.)

As was alluded to at the beginning of this essay, anthropologist Hermano Viana uses as a point of departure in his book the encounter that occurred in the 1920s between modernist writers and the more expressive samba artists of Rio de Janeiro. Such a rendezvous would represent a landmark in the idealized union of lettered erudite elites and black popular composers from subaltern urban sectors.

In an analogous manner, it seems productive to me to point out the link, during the 1940s, between regionalist and modernist intellectuals like Freyre and Rego, and soccer players of black origin like Silva, Guia, and Fausto. Though an urban sports phenomenon, propelled by the major means of mass communication in the 1930s and 1940s-radio and newspapers in particular-this modernist collaboration placed soccer on the broader terrain of popular culture. In this way, such an encounter helped achieve the modernist project of constructing national symbols. Popular music and folklore had already made this possible; yet analyses of soccer-permeated by ideas of improvisation and physical lability -also played a role in leading to an intellectual consolidation that might be called a brasilidade of sports.

\section{Works Cited}

Andrade, Mário de. "Brasil-Argentina". Os filhos da Candinha. Rio de Janeiro: Agir, 2008. 65-68. Print.

---. De Paulicéia desvairada a Café (Poesias completas). São Paulo: Círculo do Livro, n.d. Print.

---. Macunaíma, o herói sem nenhum caráter. Belo Horizonte/Rio de Janeiro: Garnier, 2001. Print.

---. O baile das quatro artes. São Paulo: Martins, 1963. Print.

Andrade, Oswald de. Memórias sentimentais de João Miramar. São Paulo: Globo, 1991. Print.

---. Pau-Brasil. Prefácio de Paulo Prado. São Paulo: Globo, 1991. Print.

---. Poesias reunidas. São Paulo: Difel, 1966. Print.

Aranha, Graça. Obra completa. Rio de Janeiro: Instituto Nacional do Livro, 1969. Print.

Archetti, Eduardo P. Masculinities: Football, Polo and the Tango in Argentina. New York: Oxford, 1999. Print.

Arrigucci Jr., Davi. Humildade, paixão e morte: a poesia de Manuel Bandeira. São Paulo: Companhia das Letras, 1990. Print. 
---. "O humilde cotidiano de Manuel Bandeira." Enigma e comentário: ensaios sobre literatura e experiência. São Paulo: Companhia das Letras, 1987. 9-28. Print.

Arruda, Genésio, dir. Campeão de futebol. 1931.

Burke, Peter. A cultura popular na Idade Moderna. São Paulo: Companhia das Letras, 1989. Print.

Campos, Paulo Mendes. "Passes de letra." Diário da tarde. Rio de Janeiro: Civilização Brasileira, 1981. 92.

Cândido, Antônio. A educação pela noite e outros ensaios. Rio de Janeiro: Ouro Sobre Azul, 2006. Print.

Filho, João Lyra. Introdução à sociologia dos desportos. Rio de Janeiro: Bloch, 1973. Print.

Filho, Mário. Copa Rio Branco 32. Prefácio de José Lins do Rego. Rio de Janeiro: Pongetti, 1943. Print.

---. Histórias do Flamengo. Rio de Janeiro: Gernasa, 1945. Print.

---. O negro no futebol brasileiro. Rio de Janeiro: Mauad, 2003. Print.

Freyre, Gilberto. Casa-Grande e senzala. Rio de Janeiro: Record, 1992. Print.

---. Interpretação do Brasil. São Paulo, Companhia das Letras, 2001. Print.

---. "Prefácio." O negro no futebol brasileiro. By Mario Rodrigues Filho. Rio de Janeiro: FAPERJ, 2003. 24-26.

---. Sobrados e mucambos. Rio de Janeiro: Record, 2000. Print.

---. Sociologia. Rio de Janeiro: José Olympio, 1967. Print.

---. Vida, forma e cor. Rio de Janeiro: Record, 1987. Print.

Gardel, André. O encontro de Manuel Bandeira e Sinhô. Rio de Janeiro: Biblioteca carioca, 1996. Print.

Machado, Antônio de Alcântara. "Corinthians (2) vs. Palestra (1)". Brás, Bexiga e Barra Funda. Rio de Janeiro: Imago, 1997. 36-41. Print.

Moraes, Eduardo Jardim de. A brasilidade modernista: sua dimensão filosófica. Rio de Janeiro: Graal, 1978. Print.

Moraes, Mário de. Futebol é arte: Domingos da Guia, Zizinho, Péle. Rio de Janeiro: MIS Editorial, 2002. Print

Ortiz, Renato. Românticos e folcloristas: Cultura popular. São Paulo: Olho D’água, 1992. Print.

Rego, José Lins do. Flamengo é puro amor. Rio de Janeiro: José Olympio, 2002. Print.

---. O vulcão e a fonte. Rio de Janeiro: O Cruzeiro, 1958. Print.

Rodrigues Filho, Mario. O negro no futebol brasileiro. Rio de Janeiro: FAPERJ, 2003. Print.

Rodrigues, Nelson. À sombra das chuteiras imortais: crônicas de futebol. São Paulo: Companhia das Letras, 1993. Print.

Romero, Sílvio. Estudos sobre a poesia popular do Brasil. Petrópolis: Vozes, 1977. Print. 
Schwarz, Roberto. O pai de família e outros estudos. São Paulo: Companhia das Letras, 2008. Print.

Sevcenko, Nicolau. "A capital irradiante: técnica, ritmos e ritos do Rio." História da vida privada no Brasil. Vol. 3. Ed. Fernando Novais. São Paulo: Companhia das Letras, 1997. 513-519. Print.

---. Literatura como missão: tensões sociais e criação cultural na Primeira República. São Paulo: Brasiliense, 1983. Print.

---. "Transformações na linguagem e advento da cultura modernista no Brasil." Estudos históricos 11 (1993): $84-87$. Print.

Soares, Antônio Jorge. Futebol, raça e nacionalidade no Brasil: releitura da história oficial. Rio de Janeiro: Tese de Doutorado em Educação Física da Universidade Gama Filho, 1998. Print.

Vianna, Hermano. O mistério do samba. Rio de Janeiro: Zahar, 1995. Print. 